\title{
Has Wind Erosion in the Source Region of the Yangtze River Been Strengthened?
}

\author{
Ling-Ling Song ${ }^{1}$, Qing Tian ${ }^{1 *}$, Zong-Jie Li ${ }^{2}$ \\ ${ }^{1}$ College of Forestry, Gansu Agricultural University, Lanzhou, Gansu, China \\ ${ }^{2}$ Key Laboratory of Western China's Environmental Systems (Ministry of Education), \\ College of Earth Environmental Science, Lanzhou University, Lanzhou, Gansu, China
}

Received: 1 January 2019

Accepted: 28 March 2019

\begin{abstract}
Through the analysis of wind deposition, wind erosion and vegetation in the source region of the Yangtze River from 2005 to 2015. The results showed that wind deposition showed a decreasing trend from 2005 to 2015. And wind erosion also showed a decreasing trend year by year. The average value of wind deposition was basically equal to wind erosion average value from 2005 to 2015. The order of average thickness of wind deposition in the source region of the Yangtze River was summer $>$ autumn $>$ winter $>$ spring. The order of average thickness of wind erosion in the source region of the Yangtze River was winter $=$ spring $>$ summer $>$ autumn. According to the change of wind deposition and wind erosion in the study area for 11 years, there was a positive correlation between wind deposition and wind erosion $(\mathrm{p}<0.01)$. Wind erosion in the source area of the Yangtze River would not bring great pressure to the opening of the Qinghai Tibet railway as protection from the government played an important role in the source area of the Yangtze. However, there was still a lot of work to be done to control desertification in the source area of the Yangtze, and to ensure the ecological safety of the source area of the Yangtze and the whole Qinghai Tibet Plateau. The results are also helpful for further understanding of the wind erosion situations in the Tibetan Plateau and providing scientific basis for the effective prevention and control of wind erosion.
\end{abstract}

Keywords: wind erosion, wind deposition, vegetation, source region of the Yangtze River

\section{Introduction}

As a result of climate change and increasing human activities, there are a series of ecological and environmental problems occurring, such as glacier retreat, grassland degradation, land desertification, hydrological system change, biodiversity reduction and so on [1-3]. And desertification is one of the most important environmental problems for the source region of Yangtze River [4-9]. The desertification of the source region of the Yangtze is mainly manifested as salinization, secondary bare soil, soil and water loss and desertification. Desertification for the source region of the Yangtze not only affects the ecological security of the source area, but also affects the sustainable development of the whole basin [10-13]. The water conservation function of regional characteristics, rich 
natural resources and biodiversity, and the importance of the ecological safety of the whole basin, the desertification development in the source region of the Yangtze has aroused widespread concern in the community and the majority of researchers, along with Heyuan River area development from different angles on scientific research [2,14-16] due to the specific function of water conservation, rich natural resources and biodiversity, and the importance of the ecological security of the whole basin for the source region of Yangtze. The development of desertification in the source region of the Yangtze has aroused the widespread concern of society and scientists who research the whole basin from different angles [17-18].

In the past 40 years, the annual average of temperature for the source area of the Yangtze has risen by $0.8^{\circ} \mathrm{C}[7,13,19]$. It is one of the regions of the highest range for temperature rise in the Tibet Plateau [20]. The increasing temperature causes increasing evaporation in the area. The climate shows a warm and dry trend while the permafrost table has a decreasing trend. Thus the original ecological environment is disturbed and further promotes the development of desertification [21-25]. Previous studies have shown that the source region of the Yangtze will increase significantly in the next 100 years. This will further result in a substantial retreat of glaciers, grassland degradation, wetland atrophy, lake shrinkage and dryness, which leads to the further development of desertification and strengthening of aeolian activities. The plateau is in the upper and middle layers of the troposphere, and the atmosphere activities are intense and frequent, which provides enough power for the sand flow and the extension of the desert [26-28]. The large floating dunes and desertification lands in the plateau to provide sufficient material for the movement of sand and the expansion of desert. This may appear on the scale of desertification in the source region of the Yangtze and the Tibetan Plateau, and the region has become China's new source of dust weather, which will affect the atmospheric dust content and China across the pacific [29-30].

It is possible that there will be large-scale desertification in the source area of the Yangtze and the whole Qinghai Tibet Plateau. The source region of the Yangtze will become new sources of dust weather [5]. This will affect the atmospheric dust content in China and even the whole pacific. For the whole Yangtze River Basin, the development of desertification in the source area will destroy the water conservation function of the source area [31] and increase soil and water loss, which will affect the stability of water flow in the middle and lower reaches of the Yangtze. Thus, it poses a threat to the ecological security of the whole basin. At the same time, it also has a negative impact on the life and production in the middle and lower reaches of the source area of the Yangtze [32-33].

In such a cold region of the Yangtze source area [11], the growth of vegetation is slow and ecological restoration is difficult, with the characteristics of desertification being unable to recover or difficult to recover. The occurrence and development of desertification will inevitably pose a great threat to the ecological security of this region. If desertification in the source area of the Yangtze is not effectively controlled and continues to develop, it is bound to undermine the region's water conservation, climate regulation and its role in biodiversity conservation. This has spurred extensive research. Through analysis of wind erosion and wind accretion in the source region of the Yangtze from 2005 to 2015 as well as the changes of vegetation in the growing season, the main purposes of this paper are: (1) analyze aeolian erosion in the source area of the Yangtze in the past 11 years; (2) investigate the influence of aeolian erosion on the ecological status of the source region of the Yangtze; and (3) evaluate the influence of aeolian erosion on the Qinghai Tibet railway. This article looked at the sandstorm erosion source region of the Yangtze River area and the influence on the source region of the Yangtze under the background of global environmental change. The results are also helpful for further provide reference data for the whole Sanjiang source protection area and the whole Qinghai Tibet Plateau in order to analyze the characteristics of desertification and its development trend and provide a scientific basis for effectively preventing and controlling desertification, while meanwhile providing scientific basis for future research.

\section{Material and Methods}

\section{Study Area}

The source region of the Yangtze River is located in the hinterland of the Qinghai Tibet Plateau at $90^{\circ} 43^{\prime} \sim 96^{\circ} 45^{\prime} \mathrm{E}, 32^{\circ} 30^{\prime} \sim 35^{\circ} 35^{\prime} \mathrm{N}$ (Fig. 1). The region covers Zhiduo County, Qumalai County, Tanggula town in Geermu city, Yushu county and Chenduo County, and the control drainage area is about $1.38 \times 10^{5} \mathrm{~km}^{2}$ [5, 14]. The basin has 5 major rivers: the Chumaer, Tuotuo, Gaerqu, Buqu and Dangqu. The source region of the Yangtze is one of the main distribution areas of the plateau wetland on the Qinghai Tibet Plateau, and is also the most concentrated area of glacier distribution in the study region. The glacier area accounts for more than $89 \%$ of the entire Sanjiang source region, while meltwater runoff accounts for more than $25 \%$ of the source region of the Yangtze. The climate in the source region of the Yangtze is a typical plateau cold climate. The characteristics of climate are characterized as low heat and strong radiation, two significant seasons (dry, wet), and rain heat over the same period. From the southeast to the northwest, differences in temperature and precipitation gradient were significant. Annual average temperature is only $3 \sim 5.5^{\circ} \mathrm{C}$. The warmest month is July, when the average temperature is $3 \sim 17.3^{\circ} \mathrm{C}$. Some areas will not even appear to have accumulated temperature higher than $10^{\circ} \mathrm{C}$. There is no 


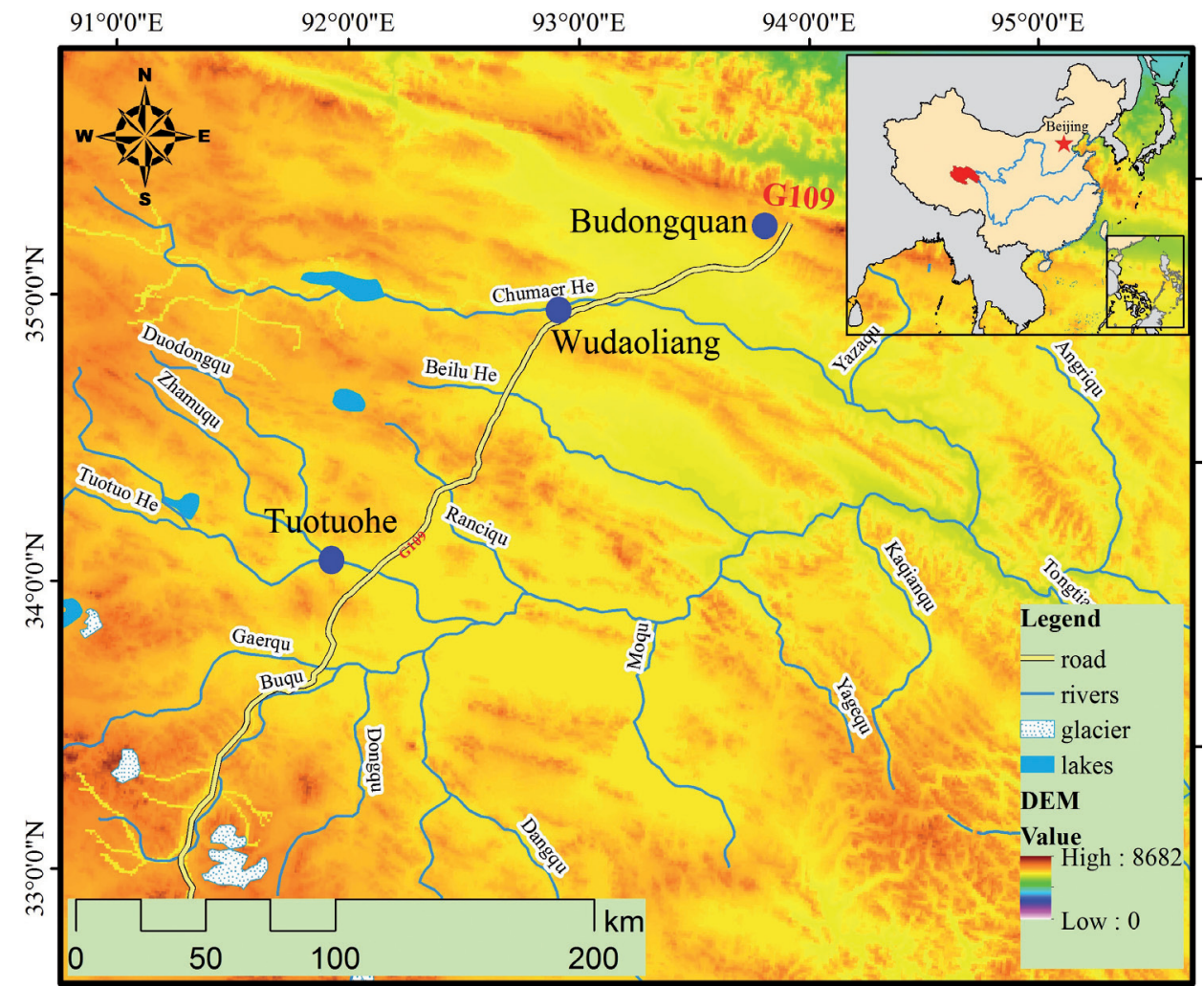

Fig. 1. Map showing the Yangtze River source region.

absolute frost-free period, and annual precipitation is 221.5 515 $\mathrm{mm}$.

\section{Observation and Analysis}

In order to study the effects of wind erosion and wind deposition on the source region of the Yangtze and the characteristics of wind erosion and wind deposition in recent years, with Budongquan, Wudaoliang and Tuotuohe as the observation point, wind erosion, wind deposition and vegetation situations in the study area were systematically observed from 2005 to 2015. Desertification (wind erosion and wind deposition) is mainly monitored by the Wind Erosion Observation System. The sampling period of each collection point is 15 or 30 seconds. Usually the sampling period is from 15 seconds to 2 hours. This system automatically records the onset time, intensity of wind erosion sediment erosion and the cumulative measurement of sediment erosion with time. The memory capacity of RAM can be continuously monitored for 80 days (5-min intervals). Measurement range is from 0 to $1200 \mathrm{~g}$ and measurement accuracy is $0.1 \mathrm{~g}$. Vegetation coverage is mainly measured by the Vegetation Coverage Observation System. The surface vegetation coverage photogrammetry system includes a portable vegetation coverage photogrammeter and automatic calculation system of surface vegetation coverage. One part is the hardware part. Even with the portable vegetation coverage photogrammeter, its function is to take vertical photographs to obtain vegetation coverage images. Another part is the PCOVER software. Its function is to process the acquired image and calculate the vegetation coverage automatically. The height of the plant is measured by steel tape.

\section{Results}

\section{The Inter-Annual Variation of Wind Deposition and Wind Erosion}

Fig. 2 shows the inter-annual variation of wind deposition and wind erosion in the Yangtze source region from 2005 to 2015. In general, wind deposition showed a decreasing trend from 2005 to 2015 (Fig. 2a), and wind erosion also showed a decreasing trend year by year (Fig. 2b). This indicated that the process of soil structure damage and the displacement of the soil particles had decreased year by year. Objectively speaking, wind erosion was mainly due to two reasons: first of all, wind speed, wind direction and other climatic factors; second was the roughness factor, which was the factor of reducing wind power. Certainly, this was closely related to the state's financial support for the protection of the Yangtze source area and the reasonable protection policies. The average value of wind deposition was basically equal to wind erosion average value from 2005 to 2015 . The average thickness of wind deposition was $0.17 \mathrm{~cm}$ and average thickness 

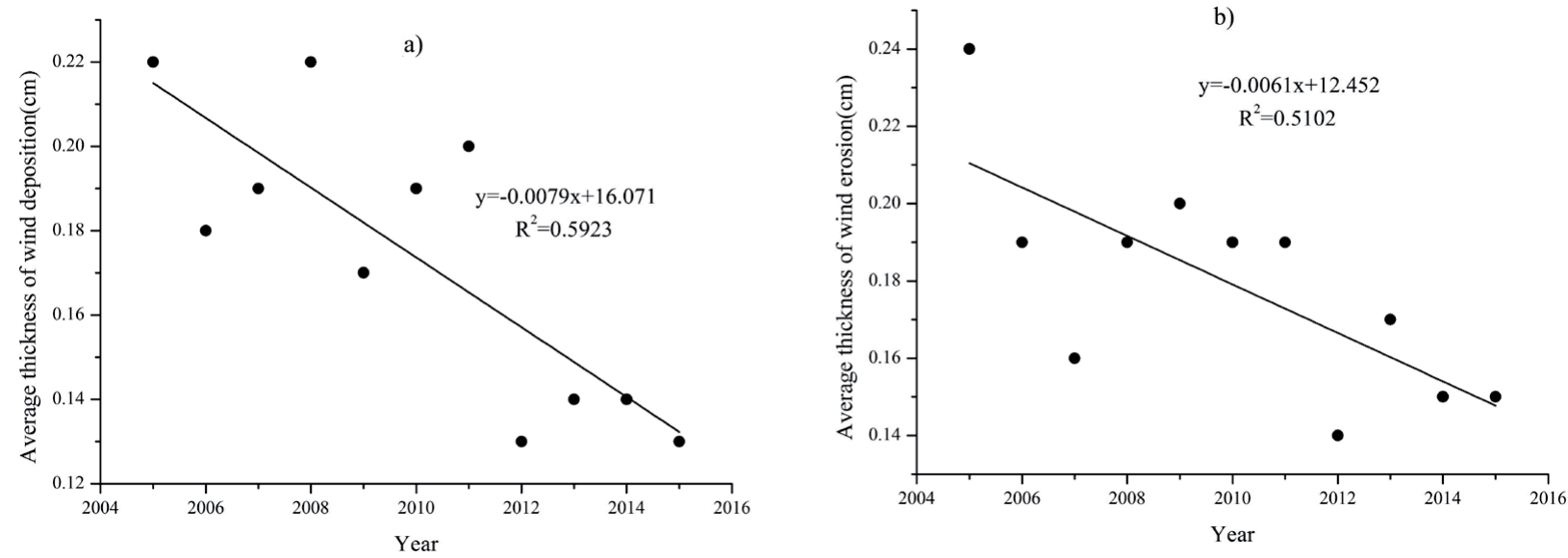

Fig. 2. Inter annual variation of wind deposition and wind erosion in the study area from 2005 to 2015.

of wind erosion value was $0.18 \mathrm{~cm}$. But the difference may be mainly contributed to the dust events in the study area. The highest value of average thickness of wind deposition was $0.22 \mathrm{~cm}$, which appeared in 2005 and 2008. And the highest value of average thickness of wind erosion appeared in 2005 , when the value was $0.24 \mathrm{~cm}$. The lowest value of average thickness of wind deposition and wind erosion all happened in 2012, but the lowest value of average thickness of wind deposition was $0.13 \mathrm{~cm}$ and wind erosion was $0.14 \mathrm{~cm}$.

\section{Seasonal Variation of Wind Deposition and Wind Erosion}

The seasonal variation of wind deposition and wind erosion is shown in Fig. 3. The order of average thickness of wind deposition in the Yangtze source region was summer $>$ autumn $>$ winter $>$ spring, with the mean values being $0.22,0.18,0.17$ and $0.16 \mathrm{~cm}$, respectively (Fig. 3a). However, the order of average thickness of wind erosion in the source region was winter $=$ spring $>$ summer $>$ autumn, with the mean values being $0.19,0.19,0.17$ and $0.16 \mathrm{~cm}$, respectively (Fig. 3b). Precipitation mainly concentrated in summer and autumn in the source region. At the same time, the growing season of plants was also concentrated in summer and autumn. So the average thickness of wind deposition in summer and autumn was higher than in spring and winter, while the average thickness of wind erosion in spring and winter was higher than in summer and autumn. Generally speaking, the average thickness of wind deposition was equal to the average thickness of wind erosion. But the average thickness of wind deposition in summer $(0.22 \mathrm{~cm})$ and autumn $(0.18 \mathrm{~cm})$ was higher than the average thickness of wind erosion(summer was $0.17 \mathrm{~cm}$; autumn was $0.16 \mathrm{~cm}$ ). It was also related to the vegetation growing season and rainy season for the source region of the Yangtze River. The average thickness of wind erosion in spring $(0.19 \mathrm{~cm})$ and winter $(0.19 \mathrm{~cm})$ was higher than in summer $(0.17 \mathrm{~cm})$ and autumn $(0.16 \mathrm{~cm})$, due to which the climate was dry, the wind speed was greater and the surface vegetation was minimal in the study area.
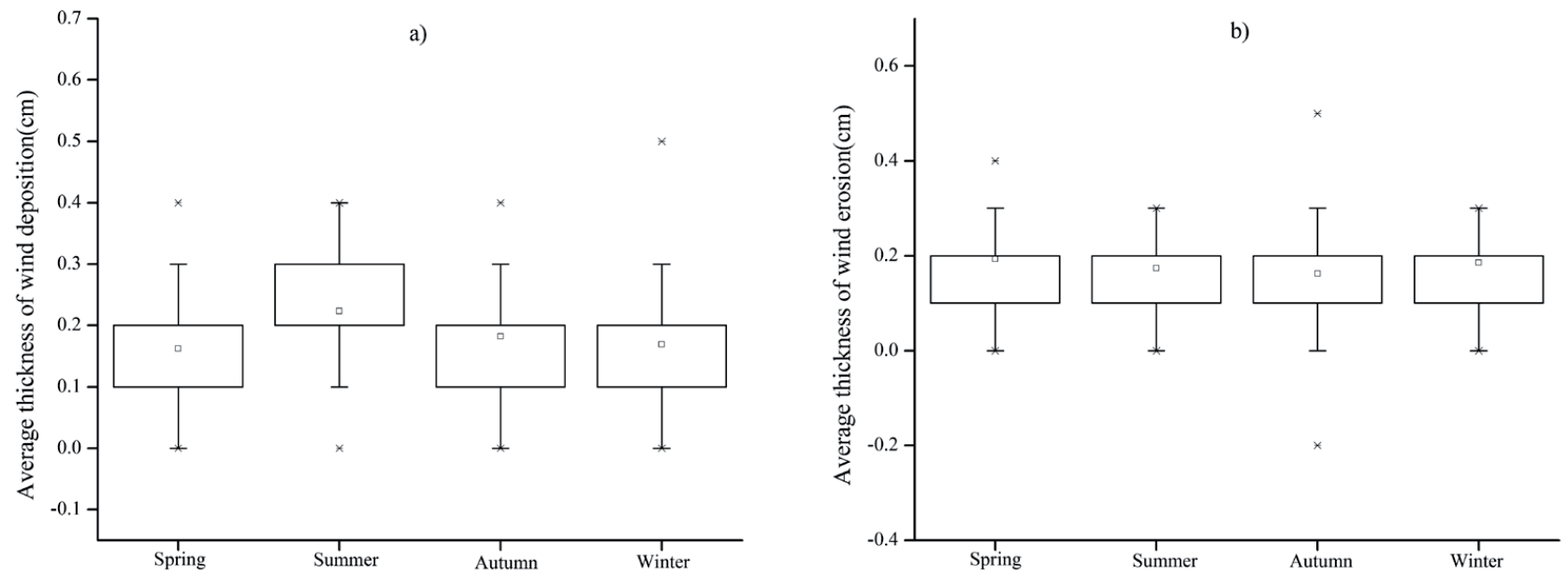

Fig. 3. Seasonal variation of wind deposition and wind erosion in the study area from 2005 to 2015. 


\section{Variation of Vegetation Condition in the Yangtze Source Region}

Fig. 4 shows the variation of vegetation conditions in the source region from 2005 to 2015. The height of herbage increased year by year (Fig. 4a), which indicated that the climate and other environmental conditions in the study area were suitable for the growth of forage. There were two reasons for this point: on the one hand, the state has carried out a policy of returning grazing land to grassland in the study area in recent years; on the other hand, the protection and restoration of the grasslands had already played a role. The highest value of herbage height was $7.25 \mathrm{~cm}$, which happened in 2012 , and the lowest value $(5.5 \mathrm{~cm})$ appeared in 2007. The variation of vegetation abundance is shown in Fig. 4b). Vegetation abundance increased year by year, but the increasing trend was weaker than that height of herbage. With the increase of forage height, the vegetation coverage should increase in the study. And the average value of vegetation coverage was $55.86 \%$, the highest was 62\% (in 2010) and the lowest (47.25\%) in 2013. However, herbage yield showed a decreasing trend from 2005 to 2015. The highest value of herbage yield was $99.75 \mathrm{~g} / \mathrm{m}^{2}$, which appeared in 2006 , while the lowest $\left(24.9 \mathrm{~g} / \mathrm{m}^{2}\right)$ appeared in 2015 . The yield of herbage was mainly related to precipitation and illumination. It also had a great relationship with topography and other environmental factors. So the fluctuation of interannual variation was very large. In addition, the grassland growth season was very short in the Qinghai Tibet Plateau.

\section{Discussion}

Analysis of the Relationship between Wind Deposition and Wind Erosion

The relationship between wind deposition and wind erosion in the Yangtze source region from 2005 to 2015 is shown in Fig. 5. According to the change of wind deposition and wind erosion in the study area over 11 years, there was a positive correlation between wind deposition and wind erosion $(\mathrm{p}<0.01)$. Wind erosion is the action of erosion and rubbingabrading for the surface by wind. Wind deposition is when sand particles stop moving and deposit because of the slowdown of wind speed [34]. The more serious the wind erosion, the stronger the wind-blown area [3, $4,17]$. The average thickness of wind deposition was $0.17 \mathrm{~cm}$ and average thickness of wind erosion value was $0.18 \mathrm{~cm}$. The average value of wind deposition was basically equal to wind erosion average value from 2005 to 2015. The overall change trend of wind erosion and wind deposition was consistent (Fig. 5b), and variation
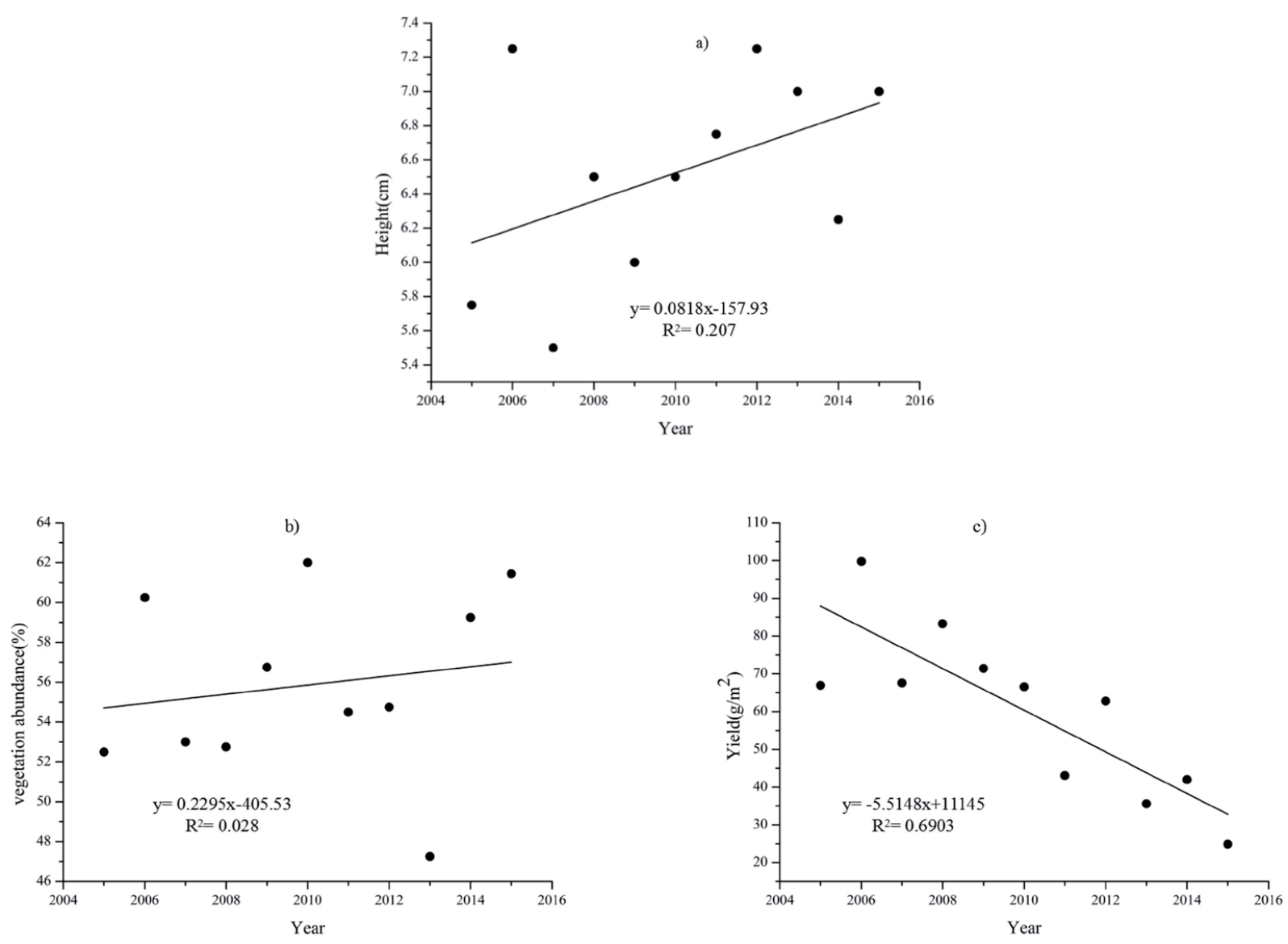

Fig. 4. Variation of vegetation conditions in the study area from 2005 to 2015. 

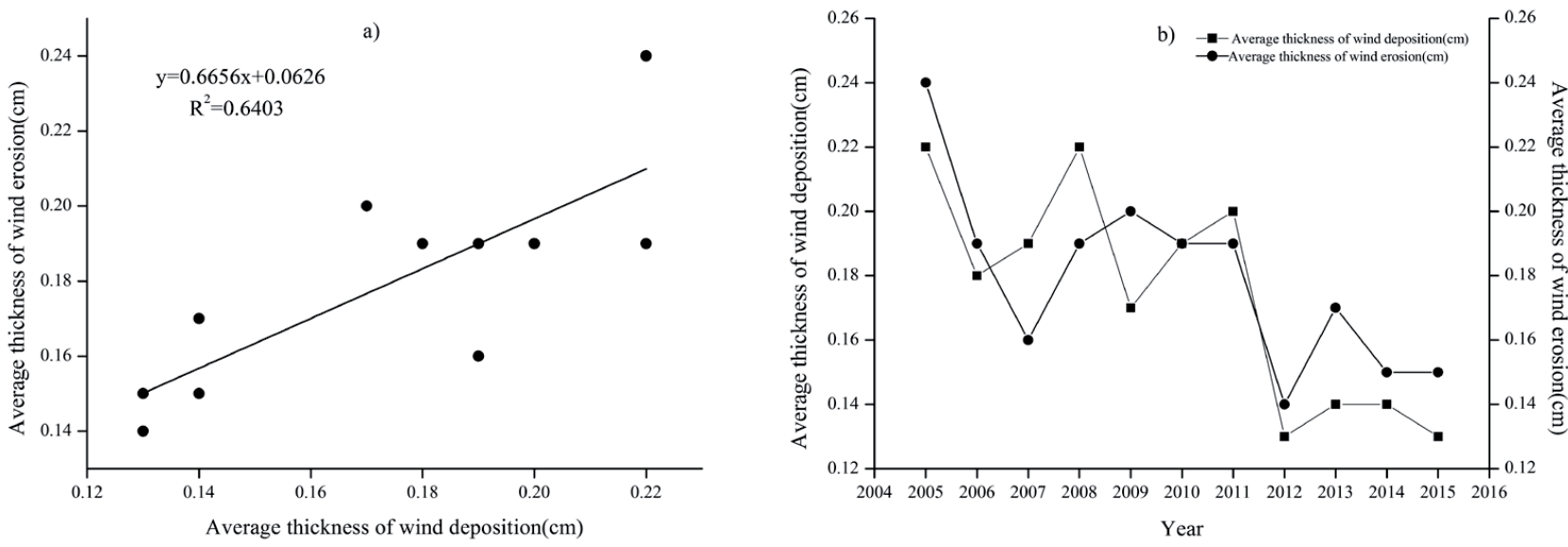

Fig. 5. Relationship between wind deposition and wind erosion in the study area from 2005 to 2015 .

range wasn't larger. This point further proved the above analysis. Wind erosion and wind deposition showed a decreasing trend from 2005 to 2015. This indicated that the wind erosion in the source area would not bring great pressure to the opening of the Qinghai Tibet railway because government protection played an important role in the source area. However, there was still a lot of work to be done to control desertification in the source area, and to ensure the ecological safety of the source area of the Yangtze and the whole Qinghai Tibet Plateau [5, 11, 13].

\section{Analysis of Relationship between Wind Deposition and Vegetation}

In order to investigate the relationship between wind deposition and vegetation in the Yangtze source region, this paper analyzed the correlations between wind
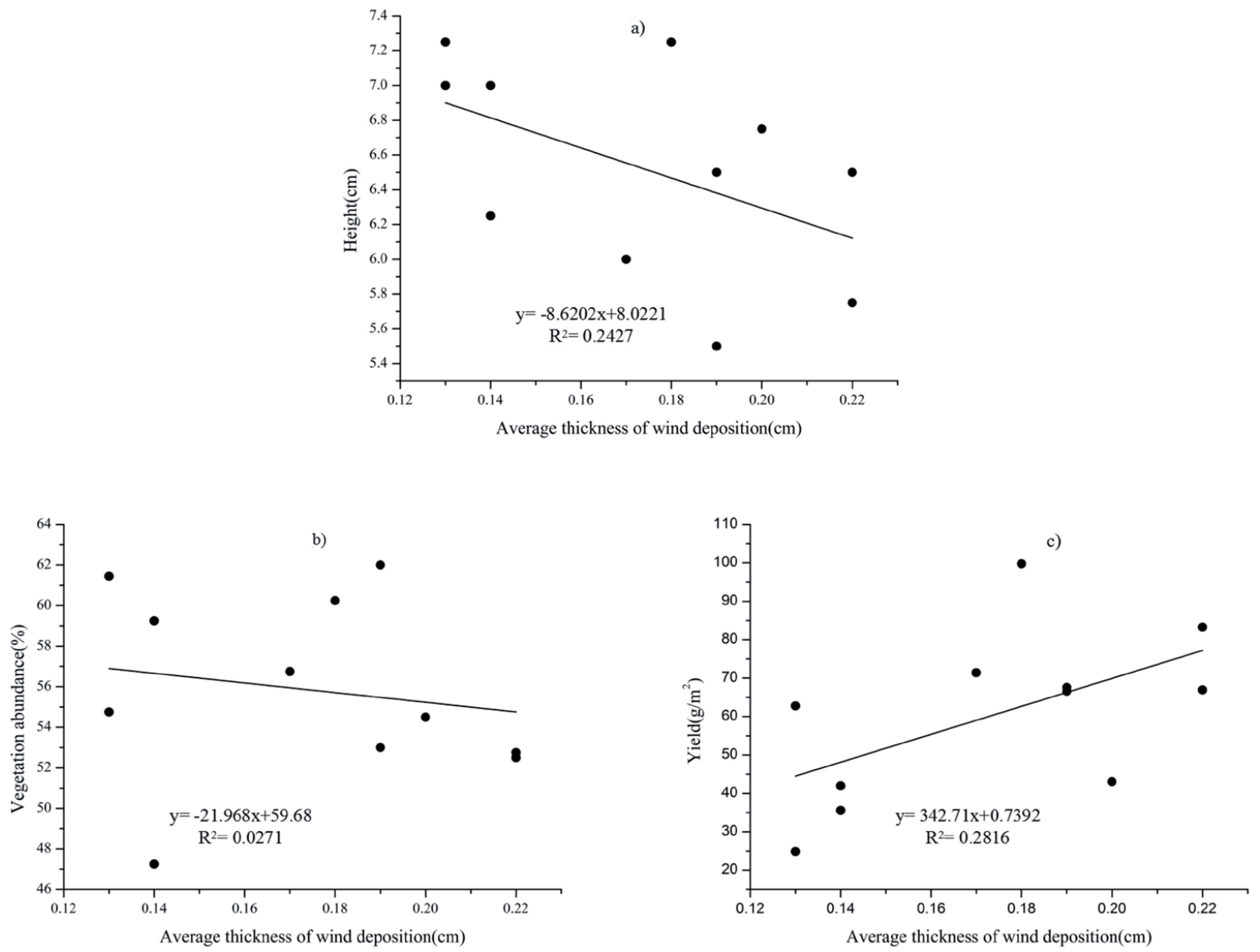

Fig. 6. Relationship between wind deposition and vegetation in the study area from 2005 to 2015 . 

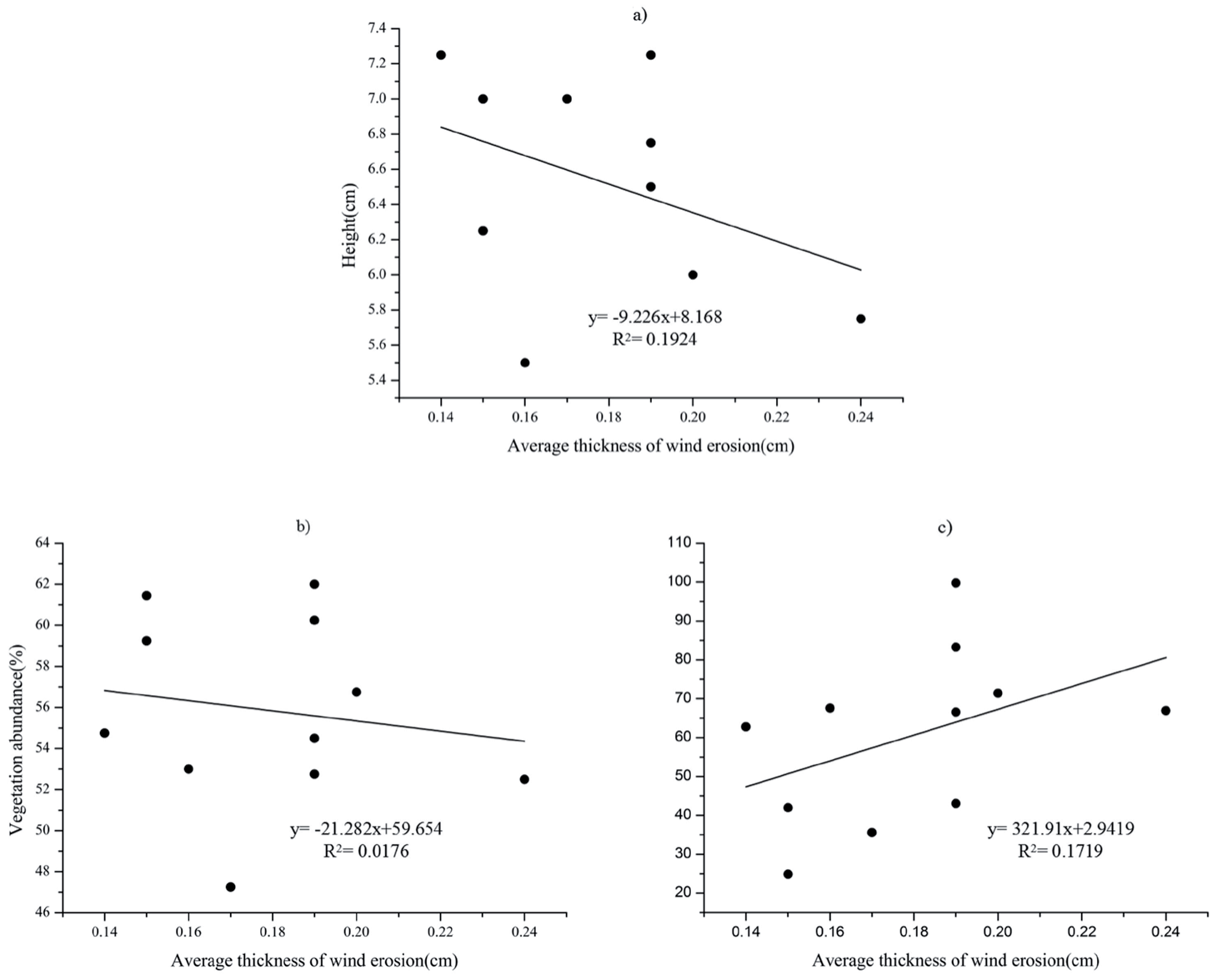

Fig. 7. Relationship between wind erosion and vegetation in the study area from 2005 to 2015.

deposition and forage height, vegetation coverage and grass yield. As shown in Fig. 6a), there was a significant negative correlation between wind deposition and vegetation height $(\mathrm{p}<0.05)$. The higher the vegetation height, the less the wind deposition. Because vegetation height was higher, the probability of wind deposition was small. The high growth of herbage played an important role in decreasing wind speed [22]. At the same time, it also had some effects on changing wind direction. Vegetation abundance was the same as forage height, and there was a negative correlation between wind deposition and vegetation abundance $(\mathrm{P}>0.05)$ (Fig. 6b). But the wind deposition showed an increasing trend with the increasing herbage yield. And the trend was more obvious $(\mathrm{P}<0.05)$. This indicated that wind deposition was helpful to increase the yield of grassland in Qinghai Tibet Plateau, which may be related to the growth of plants on the plateau. Vegetation plays an important role in desertification control and soil and water conservation in the Yangtze source area $[24,26]$.

\section{Analysis of Relationship between Wind Erosion and Vegetation}

The relationship between wind erosion and vegetation is shown in Fig. 7. The relationship between wind erosion and vegetation was the same as the relationship between wind deposition and vegetation. Wind erosion and vegetation height showed a significant negative correlation $(\mathrm{P}<0.05)$ (Fig. 7a). There was negative correlation between wind erosion and vegetation abundance $(\mathrm{P}>0.05)$ (Fig. $7 \mathrm{~b})$, and wind erosion and herbage yield showed a significant positive correlation $(\mathrm{P}<0.05)$ (Fig. $7 \mathrm{c})$. The vegetation coverage and the height of the grass on the plateau significantly reduced the damage of the strong wind to the grassland surface. At the same time, the wind speed was reduced and wind direction changed, so as to effectively protect the grassland. However, there was positive correlation between wind erosion and herbage yield. The more serious the wind erosion, the more serious the wind deposition. And wind deposition was helpful for increasing the yield of grassland. So wind erosion was also helpful for increasing herbage yield. This point further proved the significant positive correlation between wind deposition and wind erosion $[3,26]$.

\section{Conclusions}

Through the analysis of wind deposition, wind erosion and vegetation in the source region of the Yangtze River from 2005 to 2015, wind deposition 
showed a decreasing trend from 2005 to 2015. And wind erosion also showed a decreasing trend year by year. The average value of wind deposition was basically equal to wind erosion average value from 2005 to 2015. The average thickness of wind deposition was $0.17 \mathrm{~cm}$ and average thickness of wind erosion value was $0.18 \mathrm{~cm}$. The order of average thickness of wind deposition in the Yangtze River source region was summer $>$ autumn $>$ winter $>$ spring, with the mean values being $0.22,0.18,0.17$ and $0.16 \mathrm{~cm}$, respectively. However, the order of average thickness of wind erosion in the source region was winter $=$ spring $>$ summer $>$ autumn, with the mean values being $0.19,0.19,0.17$ and $0.16 \mathrm{~cm}$, respectively. According to the change of wind deposition and wind erosion in the study area over 11 years, there was a positive correlation between wind deposition and wind erosion $(\mathrm{p}<0.01)$, and a significant negative correlation between wind deposition and vegetation height $(p<0.05)$. Vegetation abundance was the same as forage height, and there was a negative correlation between wind deposition and vegetation abundance $(\mathrm{P}>0.05)$. But the wind deposition showed an increasing trend with the increasing herbage yield. And the trend was more obvious $(\mathrm{P}<0.05)$. The relationship between wind erosion and vegetation was the same as the relationship between wind deposition and vegetation. Wind erosion in the source area of the Yangtze River would not bring great pressure to the opening of the Qinghai Tibet railway; the protection from the government had played an important role in the source area of the Yangtze. However, there was still a lot of work to be done to control desertification in the source area, and to ensure the ecological safety of the Yangtze source area and the whole Qinghai Tibet Plateau.

\section{Acknowledgments}

This study was supported by the Discipline Construction Fund Project of Gansu Agricultural University (GAU-XKJS-2018-109), the Youth Tutor Fund of Gansu Agricultural University (GAU-QNDS-201602), the Open Foundation of MOE Key Laboratory of Western China's Environmental System, Lanzhou University, and the Fundamental Research Funds for the Central Universities (lzujbky-2018-kb01).

\section{Conflict of Interest}

The authors declare no conflict of interest.

\section{References}

1. HANAFI A., JAUFFRET S. Are long-term vegetation dynamics useful in monitoring and assessing desertification processes in the arid steppe, southern Tunisia. Journal of Arid Environments, 72 (4), 557, 2008.
2. FARMER J., SCHAEFFER S., ZHANG B., AN T., PEI J., ZHANG J., WANG J. How Soil Bacterial Communities with Seasonal Variation Respond Differently to Long-Term Fertilization and Plastic Film Mulching. Polish Journal of Environmental Studies, 27 (4), 1483, 2018.

3. KHEIRABADAI H., MAHMOODABADI M., JALALI V., NAGHAVI H. Sediment flux, wind erosion and net erosion influenced by soil bed length, wind velocity and aggregate size distribution. Geoderma, 323, 22, 2018.

4. LI J., OKIN G.S., ALVAREZL L., EPSTEIN H. Effects of wind erosion on the spatial heterogeneity of soil nutrients in two desert grassland communities. Biogeochemistry, 88 (1), 73, 2008.

5. QI D.M., LI Y.Q., CHEN Y.R., ZHAO X., ZHOU C.Y. The variation characteristics and causes analysis of the runoff in the source region of the Yangtze River under the background of climate change. Journal of Glaclology and Geoccryology, 37 (4), 1075, 2015. [In Chinese].

6. ZOU X., ZHANG C., CHENG H., KANG L., WU Y. Cogitation on developing a dynamic model of soil wind erosion. Science China Earth Sciences, 58 (3), 462, 2015.

7. HAYASHI S., MURAKAMI S., XU K. Q., WATANAB, M. Simulation of the reduction of runoff and sediment load resulting from the Gain for Green Program in the Jialingjiang catchment, upper region of the Yangtze River, China. Journal of environmental management, 149, 126, 2015. Armon, R. H. Desertification and Desertification Indicators Classification (DPSIR). In Environmental Indicators. Springer Netherlands. 277, 2015.

8. LIU Y., GAO P., SUN J.N., NIU X., WANG R.J. Growth Characteristics and Tree-Ring Width Response of Quercus acutissima to Climate Factors in the Rocky Mountain Area of Northern China. Polish Journal of Environmental Studies, 26 (5), 2017.

9. HE H., LI X., LI X., CUI J., ZHANG W., XU W. Optimizing the DRASTIC Method for Nitrate Pollution in Groundwater Vulnerability Assessments: a Case Study in China. Polish Journal of Environmental Studies, 27 (1), 2018.

10. D'ODORICO P., BHATTACHAN A., DAVIS K.F., RAVI S., RUNYAN C.W. Global desertification: drivers and feedbacks. Advances in Water Resources, 51, 326, 2013.

11. LI L., DAI S., SHEN H.Y., XIAO J.S. The response and trend prediction for surface water resources to climate change in the source region of the Yangtze River. Acta Geographica Sinica, 67 (7), 941, 2012 [In Chinese].

12. LIU J.Y., XU X.L., SHAO Q.Q. The spatial and temporal characteristics of grassland degradation in the ThreeRiver Head waters Region in Qinghai province. Acta GeographicaSinica, 63 (4), 364, 2008 [In Chinese].

13. JIANG Y., GAO Y., DONG Z., LIU B., ZHAO L. Simulations of wind erosion along the Qinghai-Tibet Railway in north-central Tibet. Aeolian research, 32, 192, 2018.

14. FANG Y., QIN D., DING Y. Frozen soil change and adaptation of animal husbandry: a case of the source regions of Yangtze and Yellow Rivers. Environmental Science \& Policy, 14 (5), 555, 2011

15. HU G.Y., DONG Z.B., LU J.F. Desertification Land Survey in Source Region of Yangtze River and Analysis of Its Distribution Characteristics. Journal of desert research, 30 (3), 505, 2010 [In Chinese].

16. ZHANG J., YANG M., DENG X., LIU Z., ZHANG F., ZHOU W. Beryllium-7 measurements of wind erosion on sloping fields in the wind-water erosion crisscross 
region on the Chinese Loess Plateau. Science of The Total Environment, 615, 240, 2018.

17. NIACSU L., SFICA L., URSU A., ICHIM P., BOBRIC D.E., BREABAN I.G. Wind erosion on arable lands, associated with extreme blizzard conditions within the hilly area of Eastern Romania. Environmental research, 169, 86, 2019.

18. SANTRA P., MOHARANA P.C., KUMAR M., SONI M.L., PANDEY C.B., CHAUDHARI S.K., SIKKA A.K. Crop production and economic loss due to wind erosion in hot arid ecosystem of India. Aeolian Research, 28, 71, 2017.

19. YU G.A., BRIERLEY G., HUANG H.Q., WANG Z., BLUE B., MA Y. An environmental gradient of vegetative controls upon channel planform in the source region of the Yangtze and Yellow Rivers. Catena, 119, 143, 2014.

20. PEI S., FU H., WAN C. Changes in soil properties and vegetation following exclosure and grazing in degraded Alxa desert steppe of Inner Mongolia, China. Agriculture, Ecosystems \& Environment, 124 (1), 33, 2008.

21. MAO D., LEI J., ZENG F., RAHMUTULLA Z., WANG C., ZHOU J. Characteristics of wind erosion and deposition in oasis-desert ecotone in southern margin of Tarim Basin, China. Chinese geographical science, 24 (6), 658, 2014.

22. VERON S.R., PARUELO J.M. Desertification alters the response of vegetation to changes in precipitation. Journal of Applied Ecology, 47 (6), 1233, 2010.

23. ZHOU W., SUN Z., LI J., GANG C., ZHANG C. Desertification dynamic and the relative roles of climate change and human activities in desertification in the Heihe River Basin based on NPP. Journal of Arid Land, 5 (4), 465, 2013.

24. JIA W., ZHANG C., ZOU X., CHENG H., KANG L., LIU B., LI H. Effects of ridge height and spacing on the nearsurface airflow field and on wind erosion of a sandy soil: Results of a wind tunnel study. Soil and Tillage Research, 186, 94, 2019.
25. CHAPPELL A., WEBB N.P., GUERSCHMAN J.P., THOMAS D.T., MATA G., HANDCOCK R.N., BUTLER H.J. Improving ground cover monitoring for wind erosion assessment using MODIS BRDF parameters. Remote Sensing of Environment, 204, 756, 2018.

26. WANG G.X., CHENG G.D. Characteristics of grassland and ecological changes of vegetations in the Source Regions of Yangtze and Yellow Rivers. Journal of Desert Research. 21 (2), 101, 2001 [In Chinese].

27. TUO D., XU M., GAO L., ZHANG S., LIU S. Changed surface roughness by wind erosion accelerates water erosion. Journal of Soils and Sediments, 16 (1), 105, 2016.

28. LI X.Y., LIU L.Y., WANG J H. Wind tunnel simulation of aeolian sandy soil erodibility under human disturbance. Geomorphology, 59 (1), 3, 2004.

29. FUNK R., ENGEL W. Investigations with a field wind tunnel to estimate the wind erosion risk of row crops. Soil and Tillage Research, 145, 224, 2015.

30. CHEN L., ZHAO H., HAN B., BAI Z. Combined use of WEPS and Models-3/CMAQ for simulating wind erosion source emission and its environmental impact. Science of the Total Environment, 466, 762, 2014.

31. LU R., LIU Y.F., JIA C., HUANG Z., LIU Y., HE H., WU G.L. Effects of mosaic-pattern shrub patches on runoff and sediment yield in a wind-water erosion crisscross region. CATENA, 174, 199, 2019.

32. CHEN T., ZENG D., ZHOU S. Study of Polyaspartic Acid and Chitosan Complex Corrosion Inhibition and Mechanisms. Polish Journal of Environmental Studies, 27 (4), 2018.

33. CUI H., ZHAO T., SHI H. STIRPAT-Based Driving Factor Decomposition Analysis of Agricultural Carbon Emissions in Hebei, China. Polish Journal of Environmental Studies, 27 (4), 2018.

34. LI F.R., ZHAO L.Y., ZHANG H., ZHANG T.H., SHIRATO Y. Wind erosion and airborne dust deposition in farmland during spring in the Horqin Sandy Land of eastern Inner Mongolia, China. Soil and Tillage Research, 75 (2), 121, 2004. 
